УДК 371.2: 378

DOI:

Лариса Корольова, викладач кафедри англійської філології Дніпровського національного університету імені Олеся Гончара

\title{
ПОРІВНЯЛЬНИЙ АНАЛІЗ ЕТАПІВ РОЗВИТКУ ВИЩОЇ ПЕДАГОГІЧНОЇ ОСВІТИ РУМУНІЇ ТА УКРАЇНИ
}

У статті визначено п'ять основних історичних етапів розвитку вищої педагогічної освіти, характерних для Румунї̈ та України від виникнення педагогічної думки до сьогодення. Акцентовано увагу на важливості використання системного підходу під час проведення компаративного (порівняльного) дослідження. На основі аналізу наукових робіт, документів, Інтернет-ресурсів здійснено порівняльний аналіз етапів розвитку вищої педагогічної освіти иих країн і надано їх характеристику. Визначено спільні риси та відмінності. Розкрито трансформаційні процеси, які сприяли становленню вищої освіти в Румунії та в Украӥні.

Ключові слова: вища освіта; категорія якості; Болонська декларація; управління якістю вищої освіти.

Puc. 1. Лim. 8 .

Larysa Korolova, Lecturer of the English Philology Department Dnipro Oles Honchar National University

\section{COMPARATIVE ANALYSIS OF THE STAGES OF DEVELOPMENT OF HIGHER PEDAGOGICAL EDUCATION IN ROMANIAAND UKRAINE}

The article presents the historical path of the formation and development of pedagogical education in Romania and Ukraine through a comparative retrospective analysis. And this research is due to the fact that the formation of the system of professional training of teachers in each country has its own historical path, which is determined by political, social, economic, cultural factors, as well as national and world traditions. And since today, the Ukrainian state is in the conditions of adaptation to the requirements of the common European educational space, it is very important to study the experience of professional training of future teachers in foreign countries, in particular, the neighboring country of Romania, which has a long historical and political ties with Ukraine, in order to improve the educational system of teacher education. The article also focuses on the importance of using a systems approach when conducting a comparative study. Because it is the use of a systematic approach that makes it possible to identify the theoretical basis of higher pedagogical education in each studied country and explore its main characteristics, such as: the system of management of higher educational institutions, the main legislative acts, documents, current reforms in the organization of the educational process, the types of educational institutions that implement professional training of teachers, leading universities in the field of training pedagogical personnel (general characteristics, student population, curricula.) Based on the study of scientific works, documents, Internet resources, a comparative analysis was made and five main historical stages in the development of higher pedagogical education characteristic of Romania and Ukraine from the emergence of pedagogical thought to the present (It stage - until the middle of the 19th century - Genesis, IInd stage - 20s of the XIX-90s of the XX century. The stage of the emergence of the first educational institutions and the centralized education system; III' stage - 90s of the XX century - the beginning of the XXIt stage of the creation of national systems of higher education in the post-Soviet period; IVth stage - the beginning of the XXIt century (2005-2019) stage of globalization-civilizational transformations; $V^{\text {th }}$ stage-from 2019 to the present. Distance-digital stage). A brief description of these stages is provided. Common features and differences are identified. The transformation processes that contributed to the formation of higher education in Romania and Ukraine are revealed.

Keywords: higher education; the category of quality; the Bologna Declaration; a management of the quality of higher education.

П остановка проблеми. Формування системи професійної підготовки вчителів у кожній країні має свій історичний шлях, який зумовлений політичними, соціальними, економічними, культурними чинниками, а також національними і світовими традиціями. Саме тому, сьогодні, в умовах адаптації України до вимог загальноєвропейського освітнього простору, важливим фактором, для удосконалення української системи педагогічної освіти, $€$ вивчення досвіду професійної підготовки майбутніх педагогів у зарубіжних країнах. У статті представлена сусідня країна Румунія, яка має давній історично-політичний зв'язок 3 Україною.

Метою статті $€$ визначити та охарактеризувати історичні етапи розвитку і становлення систем вищої педагогічної освіти країн Румунії та України.

Становлення і розвиток освіти як невід'ємна частина розвитку суспільства було пронизано 
наскрізними лініями певних історично-політичних подій, а тому і завдання, функції, роль і місце вчителя, а також вимоги до його професійної підготовки, постійно змінювалися. Передові мислителі й педагоги всіх часів (Я.А. Коменський, Д. Дідро, А. Дістервег, М. Пирогов, К. Каліновський, В. Дунін-Марцинкевич, Ф. Богушевич, А. Духнович, А. Макаренко, К. Ушинський, А. Богданович, В. Сухомлинський) розглядали професіоналізм учителів з позиції їх підготовки, оцінки діяльності, особистісних якостей і рівня майстерності. Сучасні ж науковці (Н. Абакшина, Н. Авшенюк, Б. Вуфольфсон, О. Глузман, Н. Лавриченко, О. Локшина, Б. Матвієнко, О. Огієнко, Л. Пуховська, C. Сапожников та ін.) масштабніше вивчають проблемні питання, пов'язані з професіональною підготовкою вчителів в системі вищої освіти, використовуючи порівняльно-історичну методику дослідження для аналізу досвіду різних країн.

Виклад основного матеріалу. Під час проведення компаративного (порівняльного) аналізу дуже важливим фактором є використання системного підходу, який дає змогу виявити теоретичний базис вищої педагогічної освіти кожної країни, що вивчається, та дослідити іiі головні характеристики: систему управління вищої освіти, основні законодавчі акти, документи, поточні реформи з організації освітнього процесу, типи закладів освіти, які здійснюють професійну підготовку вчителів, провідні виші в галузі підготовки педагогічних кадрів (загальні характеристики, контингент студентів, навчальні програми) [2].

Для створення загальної цілісної картини процесу розвитку вищої педагогічної освіти в Україні та в Румунії, яка допоможе надалі виявити закономірності та тенденції цього процесу, було проведено порівняльно-педагогічне дослідження, спрямоване на аналіз, інтерпретацію історичних подій і традицій, сучасного стану, напрямів становлення та розвитку різних систем професійної підготовки, вивчення їх взаємодії та взаємозв'язку. Застосування системного підходу, на підставі досліджень 3 історії педагогіки, науково-педагогічної літератури з історії розвитку суспільства, системи первинної та вищої освіти в Румунії та в Україні уможливило дослідити етапи розвитку вищої освіти, які є характерними для обох цих країн. Вважаємо, що їх можна представити як п’ять етапів історії розвитку вищої педагогічної освіти Румунії та України:

I етап - (до середини XIX ст.) - генезисний. У цей період виникають передумови появи педагогічної думки та наставницького навчання, коли відбувалося накопичення знань, збереження традицій, етнічної культури і суспільства. Час постійних кардинальних змін у політиці, соціумі, науці та культурі у всіх країнах світу. Функцію навчання молоді в основному брало на себе старше покоління. 3 появою християнства при монастирях створювалися школи, де навчалися майбутні церковні служителі, або діти з заможних сімей. Однак спеціальних закладів освіти для підготовки вчителів не було.

У Румунії хронологічні рамки цього етапу охоплюють період від часів романізації румунських земель (часи римської експансії, коли румунська мова на всіх рівнях поступово замінювалась на латинську) [8, 55-56] до кінця Середньовіччя, який закінчився в 1821 р. Освіта була привілеєм еліти, переважна більшість населення Румунії залишалося безграмотним майже до кінця цього періоду. Але необхідно зазначити, що у той час були спроби вивести країну на просвітницький шлях.

Перша румунська школа 3 професійної підготовки сільських вчителів була відкрита в Брашові (1495) р., який, на той момент, входив до складу Угорського королівства [7]. Оскільки то була єдина школа в цьому регіоні Трансільванії, люди приїжджали сюди здалеку. Кожне село оплачувало навчання одному учневі, якого воно обирало, з метою підготовки кадрів для села. Випускник такого закладу міг працювати: вчителем, нотаріусом або навіть священником села. У 1651p. Жужанна Лорантфі (Zsuzsanna Lorántffy), через чоловіка трансільванського князя Р. Я. Георге, запросила до Трансільванії видатного чеського філософа і педагога Яна Амоса Коменського, 3 метою підготовки педагогічної реформи. І через 6 років у (1657) в замку Фагараш було відкрито першу середню школу з румунською мовою навчання. Однак то були поодинокі спроби, які через постійні політичні зміни влади та території румунських земель, так і не призвели до поширення освітніх процесів у масштабах країни.

Зародження шкільної освіти на українських землях відбулося після хрещення Русі (988) Князь Володимир Святославович видає указ про те, що діти бояр повинні вчитися книжкової справи. Так 3'являється перша школа під назвою “Книжне вчення". За часів князя Ярослава Мудрого шкільна освіта набула розвитку. Під час татаромонгольської навали розвиток освіти призупинився. Відродження освіти відбулося майже через п'ять століть - у XVI ст., коли створювалися школи при церковних братствах. Вважають, що першим вищим навчальним закладом на території Україні є Острозька 


\section{ПОРІВНЯЛЬНИЙ АНАЛІЗ ЕТАПІВ РОЗВИТКУ ВИЩОЇ ПЕДАГОГІЧНОЇ ОСВІТИ РУМУНІЇ ТА УКРАЇНИ}

академія. Другим закладом вищої освіти була Києво-Могилянська колегія, якузасновали у 1632 р., шляхом об'єднання Київської та Лаврської братських шкіл. У 1817 р. за указом уряду КиєвоМогилянську академію було закрито, а у 1819 в їі приміщеннях відкрили Київську духовну академію.

3 наведених прикладів видно, що під час першого етапу зародження педагогічної освіти тільки в Румунії була спроба організації навчання сільських вчителів. Спеціально ж педагогічної підготовки непрактикувалося ні в Румунії, ні в Україні. Водночас з середини XVI ст. починає розвиватися промисловість і виникає потреба в елементарній освіті, а водночас - і в педагогічних кадрах.

II етап (20-ті pp. XIX - 90-ті pp. XX ст.) виникнення перших навчальних закладів i централізованої системи освіти. Аналіз історичного матеріалу, науково-дослідницьких робіт та Інтернет-джерел показав, яким складним, повним геополітичних, економічних та соціальних перетворень видався цей період для народів Румунії та України.

У Румунії цей етап розвитку вищої педагогічної освіти відкриває революція Тюдора Владіміреську (1821). Саме ця подія стала відправною точкою формування сучасної румунської держави i започаткувала процес побудови національної системи освіти, який тривав протягом усього XIX ст. Відкриваються різні типи навчальних закладів (розвинені, початкові школи, гімназії, коледжі, пансіони, університети і т.). Видається ціла низка законів з організації і функціонування системи освіти (Regulamentul Organic, legea lui Cuza, legile lui Spiru Haret та інші). Утворюються заклади зі спеціальної підготовки вчителів, переважно для початкових класів та середньої школи: семінарії, педагогічні класи, вчительські курси, учительські інститути.

У 1864 р. володар Олександру Іоан Куза затвердив перший Закон про публічне навчання, який регулював організацію та функціонування системи освіти. Відповідно до цього, державне навчання поділялося на три основні цикли: початковий, середній і вищий $[4,2]$. Через два роки у (1866) з'являється перша Постанова про порядок і дисципліну для середніх шкіл і гімназій, а в 1870 р. - для початкових шкіл. Правила встановлювали права і обов'язки як учнів, так і вчителів, правила поведінки в школі і за їі межами, систему покарань і заохочень і т. д. [5]. У 1880-і p. реформування освітньої системи Румунії продовжив міністр освіти Спіру Харет. Він створив програму реформування і модернізації освіти, яка передбачала створення у сільській місцевості широкої мережі. Така реорганізація модернізувала систему освіти Румунії і підняла на новий щабель розвитку педагогічну освіту.

Період з 1918 до 1944 рр. видався для румунської системи освіти непростим. Після 1918 р. відбулося об'єднання чотирьох історичних провінцій Румунії, Буковини, Трансільванії і Бессарабії, а це аналізувало, проблему інтеграції чотирьох різних систем освіти.

За часів фашистської окупації світової війни багато професорського та викладацького складу було або вбито або відправлено до Німеччини, всі освітні процеси майже припинилися, після визволення Румунії Радянським союзом вони стали радикально іншими. Постановою № 175 від 3 серпня 1948 року в школах Румунії ввели систему єдиного підручника. Спочатку то були просто переклади радянських підручників. Згодом їх писали румунські науковці, але пропагандистська складова залишилася [6]. У період з 1949 до 1958 р. вся система освіти перебувала під контролем Комуністичної партії Румунії за підтримки Радянського Союзу. Всі школи були розділені на три рівні (шкільні групи, середні школи і університети), які пропонували однакову освіту для всіх.

Схожі риси ми можемо прослідкувати і в становленні української педагогічної освіти під час другого етапу. XIX ст. для України також ознаменувалося новими освітніми реформами: виникнення Міністерства народної освіти, установи управління освітою і навчальними закладами стають ієрархічно підпорядковані, відбувається розподіл країни на навчальні округи, навчальні заклади поділяються на розряди (губернські, повітові, приходські та університети.

Наприкінці XVIII - на початку XIX ст. в Україні спеціальною підготовкою педагогів займалася лише Києво-Могилянська академія, але, починаючи 31811 р., наступає час розвитку національної педагогічної освіти. I новітнім історичним кроком в цьому напрямку і відкриття першого педагогічного інституту при Харківському університеті.

У радянський період професійну підготовку педагогічних кадрів у межах педагогічної освіти здійснювали: для початкової школи - педагогічні технікуми, педкласи середніх шкіл, короткотривалі курси, для середньої та старшої школи педагогічні інститути та університети.

Під час Другої світової війни, навчальні заклади всіх рівнів частково евакуйовувалися до безпечних місць (наприклад, у Східні райони СРСР, республік Середньої Азії та Закавказзя), 
частково припиняли освітню діяльність, а деякі продовжували працювати навіть під час окупації. На кінець 1943 року у зв’язку з нестачею кадрів були відкриті курси: чотиримісячні - для підготовки вчителів I-IV кл. і шестимісячні викладачів V-VII кл. [1, 308]. Після Великої Вітчизняної Війни почався етап відбудови і розвитку вищої педагогічної освіти України (19451961). У цей період система підготовки педагогічних кадрів в Україні стабілізувалася. Педагогічну підготовку майбутніх вчителів здійснювали педагогічні інститути та університети за єдиними навчальним планом Міністерства вищої і середньої освіти СРСР. Процес удосконалення вищої педагогічної посвіти продовжувався майже, до кінця 70-х XX ст., але після прийняття реформи загальноосвітньої і професійної школи (1984) посилилася тенденція фінансування вишів за залишковим принципом, матеріальна база перестала відновляється, а план прийому студентів до педагогічних навчальних закладів Держпланом України збільшувався. Розпад Радянського Союзу і створення незалежної української держави поставило на порядок денний важливе питання реорганізації та реформування національної освітньої системи.

III етап (90-ті рр. XX ст. - початок XXI ст.) створення національних систем вищої освіти у пострадянський період. Цей час видався для як для Румунії, так і для України і радісним, (довгоочікувана незалежність), і водночас повним проблемних питань з державотворення. Усі сфери діяльності підлягали реформуванню. Система освіти також стала одним з об'єктів реформування, основним завданням якого було створити нормативно-правову базу діяльності закладів вищої освіти. Початок глобалізаційних процесів в освіті, у зв'язку із створенням Європейського Союзу, підписання Лісабонської декларації, приєднання Румунії та України до Болонського процесу є характерною рисою цього етапу розвитку та становлення педагогічної освіти в обох країнах.

У Румунії після 1990 року система освіти змінилася докорінно (див. рис. 1), а реформування задля демократизації освіти розпочалося саме 3 університетів (“Закон про національну освіту”, 1995). Першим, вжитим румунським урядом кроком у цьому напрямку була автономія, яку отримали всі заклади вищої освіти, на відміну від

Міністерство освіти та науки
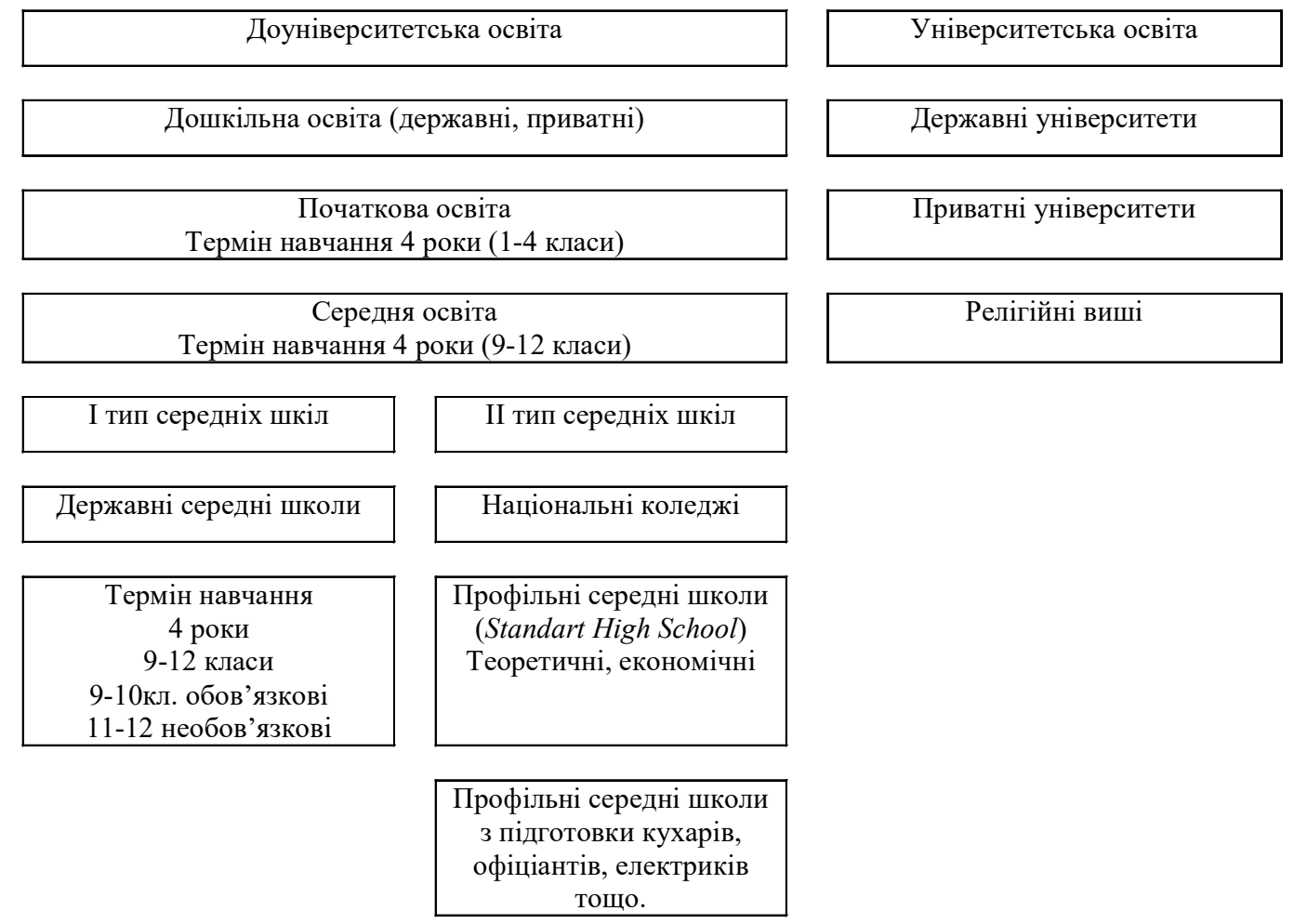

Рис. 1. Система освіти Румунії у пострадянські часи

175 Молодь і ринок №3-4 (182-183), 2020 


\section{ПОРІВНЯЛЬНИЙ АНАЛІЗ ЕТАПІВ РОЗВИТКУ ВИЩОӤ ПЕДАГОГІЧНОЇ ОСВІТИ РУМУНІЇ ТА УКРАЇНИ}

довузівського сектора. Кожен університет отримав право розв'язувати абсолютно будь-які питання у межах своєї установи - від призначення адміністрації до вибору курсів. Більше того, згодом у багатьох університетах автономними стали і факультети. Основним напрямом у сфері вищої освіти румунський уряд уважав адаптацію до європейської системи вищої освіти, тому Румунія брала участь у численних програмах $\mathrm{i}$ проєктах, які пропанував Свропейський Союз: Tempus, CEEPUS, Socrates, Erasmus, Copernicus, Monet, eLearn [3, 154].

У 1999 р. Румунія серед 29 інших країн Свропи стала учасником Болонського процесу, підписавши Болонську декларацію, і тим самим взявши на себе зобов'язання інтегрувати поставлені Радою Європи і ЮНЕСКО цілі в пріоритети румунського вищої освіти.

Що стосується України, то переосмислення законів, майже у всіх сферах українського суспільства наприкінці ХХ ст., було характерною ознакою прагнення молодої держави до набуття самоідентичності. Однак прийнятий 26 травня 1991 р. ВР УРСР Закон “Про освіту”, ще до проголошення Незалежності (24 серпня 1991р.), залишався чинним до 2020 р., хоча протягом цього часу постійно коригувався і змінювався. У період з 1992 р до 1995 р. знизилось фінансування закладів вищої освіти, почали появлятися та узаконюватися перші приватні виші. 31996 до 2000 p. розширюється та збагачується нормативно правова база вищої освіти. У 2002 р. в Україні було прийнято Закон “Про вищу освіту”, який був самостійним документом, що визначав організацію і діяльність закладів освіти. Після 2000p. і до 2005p. відбувається активний пошук нових шляхів та підходів 3 вдосконалення організації системи вищої освіти, в тому числі через дослідження зарубіжного досвіду, запускаються інтеграційні процеси, відбувається розвиток неперервності (“lifelong learning”) та ступневості (чотири ступені підготовки спеціалістів: молодший спеціаліст, бакалавр, спеціаліст, магістр).

IV етап (початок XXI ст. (2005-2019) глобалізаційно-цивілізаційних перетворень цей етап розвитку педагогічної освіти в Румунії та Україні характеризується подальшою інтеграцією в глобалізаційні процеси єдиного європейського простору вищої освіти відповідно до підписаної Болонської декларації.

Європейські освітні глобалізоційно-цівілізаційні тенденції зумовили зміну пріоритетів в освітній діяльності, акцент робиться на студоцентризм (розвиток індивідуальних задатків і нахилів кожного студента), відбувається трансформація форм, прийомів та методів навчання, оновлюється iii зміст. Також можна виокремити й інші спільні характеристики в розвитку вищої педагогічної освіти обох країн: наскрізне навчання у напрямку сталого розвитку, інформатизація освітнього процесу, ІКТ-компетентність, розвиток критичного мислення, впровадження Інтернет-ресурсів і хмарних технологій в освітню діяльність. 3 вищезазначеного можна зробити висновок, що під час IV етап розвитку педагогічної освіти все більше з'являється спільних рис у становленні вищої освіти в галузі професійної підготовки майбутніх педагогів як в Румунії, так і в Україні.

$\mathrm{V}$ етап (з 2019 р. дотепер) дистанційноцифровий завершальний етап розвитку педагогічної освіти в Румунії та Україні є новітнім періодом, який починається в епоху цифровізації суспільства, розвитку і становлення міжнародної дистанційної системи освіти. Стимулюючим фактором виникнення цього феномена $є$ низка об'єктивних причин таких як: інтенсивний технологічний прогрес, цифровізація суспільства, міжнародне Інтернет-навчання (профільні курси, Інтернет-школи, групові та індивідуальні заняття, тренінги), пандемія COVID-2019. Останній фактор, на нашу думку, був одним $з$ основних чинників, виникнення ідеї створення міжнародної системи вищої дистанційної освіти, над якою сьогодні інтенсивно працюють майже всі цивілізовані країни світу.

Висновки. Проведений порівняльний аналіз етапів розвитку педагогічної освіти в Румунії та Україні показав, що за період ії становлення від часів виникнення педагогічної думки до сьогодення, вона пройшла етапи трансформацій: відкриття вчительських семінарій, педагогічних курсів, вищих навчальних закладів, формування нормативно-правової бази вищої освіти в рамках становлення національної системи освіти та їі постійне реформування відповідно до міжнародних освітніх тенденцій. Усі ці трансформації відбувалися під впливом зовнішніх і внутрішніх соціально-політичних та економічних факторів. Подальшого вивчення потребують питання професійної підготовки вчителів у Румунії.

\section{ЛІТЕРАТУРА}

1. Вітвицька С.С. Основи педагогіки вищої школи. Підручник за модульно-рейтинговою системою навчання для студентів магістратури. Київ, 2006. 384 с.

2. Глузман А. В. Университетское педагогическое образование : опыт системного исследования : моногр. Київ, 1997. 312 с. 
3. Корольова Л.В. Сучасні аспекти підготовки вчителя іноземної мови у Румунії в загальноєвропейському вимірі. Молодь і ринок, №1(168), 2019, c. 152-155.

4. Boerescu, V. Codicele român sau Coleciune de legile principatelor Unite Române, Tipografia Cesar Bolliac, 1865, p. 173

5. Bujoreanu, I. Coleciune de legiuirile României vechi 'i noi câte s-au promulgat până la finele anului 1870, Bucure'ti, 1873 pp. $1875-1880$

6. Manualele vremurilor noi (2007) URL: $\underline{\text { https:// }}$ www.9am.ro/stiri-revista-presei/2007-09-17/ manualele-vremurilor-noi.html (дата звернення: 27.08.2020)

7. Oltean V. Prima şcoală românească - Începuturi asile. URL: https://destinatii.liternet.ro/articol/68/ Vasile-Oltean/Prima-scoala-romaneascaInceputuri.html (дата звернення: 27.08.2020)

8. Mihail, C., The (Daco-) Limbajul militar (daco)roman ' $i$ influena sa asupra limbii ' $i$ istoriei poporului român, Editura Militară, 2012, p. 55-56

\section{REFERENCES}

1. Vitvytska, S.S. (2006). Osnovy pedahohiky vyshchoi shkoly: Pidruchnyk za modulnoreitynhovoiu systemoiu navchannia dlia studentiv mahistratury [Fundamentals of Higher Education Pedagogy: A Textbook on the Modular Rating System of Education for Master's Students]. Center for Educational Literature. Kyiv, 384p. [in Ukrainian].

2. Hluzman, A. V. (1997). Unyversytetskoe pedahohycheskoe obrazovanye : opyt systemnoho yssledovanyia [University pedagogical education: the experience of systems research]. Kyiv, 312 p. [in Ukrainian].

3. Korolova, L.V. (2019). Suchasni aspekty pidhotovky vchytelia inozemnoi movy u Rumunii v zahalnoievropeiskomu vymiri [Modern aspects of training the foreign language teachers in Romania in conformity the European dimension] Youth \& market, Vol.1(168), pp.152-155. [in Ukrainian].

4. Boerescu, V. (1865). Codicele român sau Coleciune de legile principatelor Unite Române, Tipografia Cesar Bolliac [Romanian Codes or Collection of the laws of the United Romanian principalities, Cesar Bolliac Printing House]. p. 173. [in Romanian].

5. Bujoreanu, I. (1873). Coleciune de legiuirile României vechi 'i noi câte s-au promulgat până la finele anului 1870 [Collection of laws of old and new Romania, issued before the end of 1870]. Bucure'ti, pp. 1875-1880 [in Romanian].

6. Manualele vremurilor noi (2007). Available at: https://www.9am.ro/stiri-revista-presei/2007-09-17/ manualele-vremurilor-noi.html (Accessed 27 Aug 2020). [in Romanian].

7. Oltean, V. Prima şcoală românească Începuturi asile. Available at: https:// destinatii.liternet.ro/articol/68/Vasile-Oltean/Primascoala-romaneasca-Inceputuri.html (Accessed 27 Aug. 2020) [in Romanian].

8. Mihail, C. (2012). The (Daco-) Limbajul militar (daco-)roman 'i influena sa asupra limbii 'i istoriei poporului român, Editura Militară, pp. 55-56. [in Romanian].

Стаття надійшла до редакції 30.06.2020

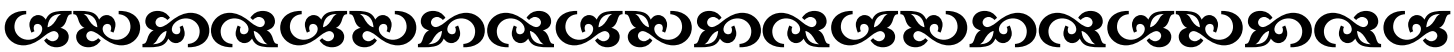

"Толовною метою освіти є створення людини, здатної робити нове, а не повторювати те, що вже зроблено прийдешніми поқоліннями”.

$$
\begin{array}{r}
\text { Жан Тіаже } \\
\text { швейцарський психолог } і \text { боілособб }
\end{array}
$$

“Будьте уважні до свойх думоқ: саме вони - початоквчинків”.

1ao-uзu

китайський фіхтософ

"ТТи робиш найқращу $і$ для тебе рятівну справу, коли твердо ступаєш по шляху доброго глузду".

Тригорій Сковорода ураӥнський бінособ, поет, педагог

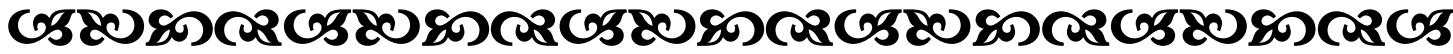

